\title{
Burnout syndrome among multinational nurses working in Saudi Arabia
}

\author{
Page|226 Haifa A. Al-Turki, Rasha A. Al-Turki ${ }^{1}$, Hiba A. Al-Dardas ${ }^{1}$, Manal R. Al-Gazal ${ }^{1}$, \\ Ghada H. Al-Maghrabi ${ }^{1}$, Nawal H. Al-Enizi ${ }^{1}$, Basema A. Ghareeb ${ }^{1}$ \\ Department of Obstetrics and Gynecology, College of Medicine, University of Dammam and ${ }^{1}$ Nursing, King Fahd \\ University Hospital, AlKhobar, Saudi Arabia
}

Correspondence to: Dr. Haifa A Al-Turki, PO Box 40286, King Fahd University Hospital, AlKhobar 31952, Saudi Arabia. E-mail: drhturki@hotmail.com

\begin{abstract}
Background: Nursing Staff is reported to be under extreme state of stress, leading to burnout syndrome (BS). Most of the studies have been conducted among the nurses working in their home countries. This study was conducted to assess the prevalence of BS among a multinational nursing workforce in Saudi Arabia.

Materials and Methods: King Fahd University Hospital, AlKhobar, Saudi Arabia, is a tertiary care hospital employing 510 nurses of multinational workforce. Two hundred and fifty Maslach Burnout Inventory (MBI) individual-based questionnaires were distributed after modification to include the age, sex, marital status, nationality, unit working and number of years on the job. The data were entered in the database and analyzed using Statistical Package for the Social Sciences (SPSS), version 14.0. A $P$ value of $<0.05$ was considered statistically significant .

Results: One hundred and ninety-eight nurses (77.2\%) completed the questionnaire. Their average age was 34.46 \pm 5.36 years. Forty-five percent (89) had high emotional exhaustion (EE) and $28.9 \%(57)$ had moderate suffering with EE. Staffs who were on the job for longer duration had a lesser frequency of $\mathrm{EE}(P \leq 0.001)$. The frequency of depersonalization (DP) was $83(42 \%)$ and was graded as high and $61(30.8 \%)$ were moderately affected. Personal accomplishment (PA) was moderate to low in the majority of the nurses $(71.5 \%)$. Married nurses were prone to $\mathrm{EE}$ (28.17 \pm 12.1 versus $22.3 \pm 9.6$ ) than unmarried nurses $(P=0.003, \mathrm{CI} 95 \%$ and OR 2.4$)$. The nurses in the patients' wards and clinics were more emotionally exhausted with higher DP compared to nurses in the high stress and high activity areas $(P<0.001, \mathrm{OR}-11.1$; and $P<0.001, \mathrm{CI} 95 \%$ and OR 9.65). Non-Saudi nurses were significantly more prone to EE $(27.3 \pm 12.1$ versus $21.6 \pm 2.9)$ than Saudi nurses $(P=0.004 ; 95 \% \mathrm{CI}:<9.64)$.

Conclusion: We found that majority of the nursing staff at our hospital were in a state of burnout with high frequency of EE and DP. Only a quarter of the surveyed staff felt that they had some level of PA. Age and working away from their home countries were the important predictors in the development of BS in nurses. We believe that working conditions have to be improved to develop strategies to cope and alleviate stressful situations.
\end{abstract}

Keywords: Burnout syndrome, emotional exhaustion, Maslach burnout inventory, nurses, Saudi Arabia

\section{Résumé}

Arrière-plan: Du personnel infirmier est déclaré sous état extrême du stress, conduisant à un syndrome d'épuisement professionnel (BS). La plupart des études ont été menée entre les infirmières travaillant dans leur pays d'origine. Cette étude a été menée afin d'évaluer la prévalence d'IP entre une main-d'œuvre infirmière multinationales en Arabie saoudite.

Matériel et méthodes: Roi Fahd CHU, AlKhobar, Arabie saoudite, est un hôpital de soins tertiaires employant 510 infirmières de main-d'œuvre multinational. Deux cent cinquante Maslach Burnout inventaire (MBI) basé sur l'individu questionnaires ont été distribués après modification pour inclure l'âge, sexe, l'état matrimonial, nationalité, unité de travail et nombre d'années sur la tâche. Les données ont été entrées dans la base de données et analysées à l'aide du progiciel de statistiques pour les sciences sociales (SPSS), version 14.0. Une valeur de $P$ de $<0,05$ était considérée comme statistiquement significative.

Résultats: Un cent quatre-vingt-dix-huit infirmières $(77,2 \%)$ rempli le questionnaire. Leur âge moyen était à \pm

Vol. 9, October-December, 2010

Annals of African Medicine 
34,46 ans 5.36. Quarante-cinq pour cent (89) avait épuisement émotionnel haute (EE) et $28,9 \%$ (57) souffrance modérée avec équité en emploi. Les équipes qui étaient au travail pour une durée plus longue avaient une moindre fréquence d'équité en emploi $(P<0,001)$. La fréquence de dépersonnalisation (DP) était $83(42 \%)$ et a été classée comme élevé et $61(30,8 \%)$ étaient modérément affectés. Réalisation personnelle $(\mathrm{PA})$ a été modérée à faible dans la plupart des infirmières (71,5\%). Infirmières mariés étaient sujettes à EEPSEA ( $28.17 \pm 12.1$ versus 22,3 \pm 9.6$)$ que les infirmières non mariés $\left(P=0,003, \mathrm{CI} 95^{\circ}\right.$ et ou 2.4). Les infirmières dans les quartiers et les cliniques des patients étaient plus émotionnellement épuisés avec DP plus élevé par rapport aux infirmières dans les zones de haute activité et de stress élevé ( $P<0.001, \mathrm{OR}-11.1$; et $<0.001$, CI 95ำ et 9,65 OR). Non-Arabie infirmières ont été considérablement plus enclins à EEPSEA ( $27,3 \pm 12.1$ versus $21,6 \pm 2,9)$ que les infirmières de l'Arabie saoudite $(P=0,004 ; 95$ 드: < 9.64).

Conclusion: Nous avons trouvé cette majorité de l'infirmière personnel à notre hôpital était dans un état de burnout avec haute fréquence d'équité en emploi et DP. Seulement un quart du personnel interrogé estime qu'ils avaient certaine PA. Âge et travailler loin de leur pays d'origine ont été les indicateurs importants dans le développement d'IP infirmières. Nous pensons que des conditions de travail doivent être améliorées pour élaborer des stratégies pour faire face et de soulager des situations stressantes.

Mots-clés: Syndrome d'épuisement professionnel, épuisement émotionnel, infirmières, Arabie saoudite, le Maslach burnout stock

\section{Introduction}

Burnout Syndrome (BS) was described for the first time by Freudenberger, an American phychoanalyst ${ }^{[1]}$ in 1974, and later Maslach (1976) ${ }^{[2]}$ gave the scientific concept, importance of early diagnosis and timely interference. There is no universally accepted definition for BS but many authorities believe that BS has a complex of symptoms of primarily exhaustion, in response to prolonged emotional and interpersonal stress at work, leading to depersonalization. ${ }^{[3]} \mathrm{BS}$ is common among certain professions which require high commitment, motivation and have high standards and require idealistic dedication to their jobs, like police personnel, judges, social workers and health care workers. ${ }^{[4]}$

Many researchers have indicated that BS is quite common among doctors and nurses. ${ }^{[5,6]}$ Orzechowska $e a^{\left[l^{[7]}\right.}$ found in their study that BS was more common among nurses in comparison to doctors. Cano et al ${ }^{[8]}$ reported that $14.4 \%$ of their study group were moderately burnout. The prevalence of BS among nurses differs from unit to unit of their work. Braithwaite ${ }^{[9]}$ reported that nurses in neonatal intensive care unit (ICU) experience high levels of psychologic and physical stress which leads to burnout, whereas Raggio and Malacarne ${ }^{[10]}$ found that BS in ICU is common and is influenced by the position of the staff and the gender.

Why should hospitals worry about BS? It has been shown that emotional exhaustion (EE) can lead to staff conflicts, absenteeism, lowered morale, and decreased productivity, which finally ends up in the staff suffering from BS and the end result is deficient and compromising patients' care. ${ }^{[11,12]}$
Over $70 \%$ of the nursing workforce in Saudi Arabia is from foreign countries and this adds to the stress of their professional work. No studies have been undertaken in the country to assess the prevalence of BS among the nurses. We have undertaken this study to investigate the prevalence of burnout among the nurses and secondly to identify factors that may contribute to the development of BS.

\section{Materials and Methods}

Before the study was instituted, approval from the Research and Ethical committee of College of Medicine, University of Dammam and King Fahd University Hospital, was obtained. Maslach Burnout Inventory (MBI) individual-based questionnaire was modified to include the age, sex, marital status, nationality, unit working and number of years on the work force and was distributed among all the nurses of King Fahd University Hospital, which is a tertiary care center of the Eastern Province of Saudi Arabia. There is a multinational work force of nursing staff in this hospital. All the nurses were explained the importance of the study, and the importance of giving truthful answers was emphasized. Three factors that the MBI assessed were EE, depersonalization (DP) and personal accomplishment (PA). The data were entered in the database and analyzed using using Statistical Package for the Social Sciences (SPSS, version 14.0, Chicago, II, USA). A $P$ value of $<0.05$ was considered to be statistically significant, with a confidence interval of 95\%. Descriptive statistics were expressed as mean $\pm \mathrm{SD}$, unless otherwise mentioned. All the variables were tested and the means compared using Student's $t$-test. Categorical data were analyzed using $\chi^{2}$ or Fisher's exact test, as appropriate. 


\section{Results}

One hundred and ninety-eight nurses (79\%) completed the questionnaire. The average age was $34.46 \pm 5.36$ years (range 24-56). The mean duration of work at the hospital was $71.6 \pm 60$ months (range 24-300). Table 1 gives the prevalence of EE. Forty-five percent (89) had high EE and $28.9 \%$ (57) had moderate EE. Staffs who were on the

job for longer duration had a lesser frequency of EE $(P 0.001)$. Table 2 gives the frequency of DP. Eightythree $(42 \%)$ of the staff had high depersonalization and $61(30.8 \%)$ were moderately affected. PA was moderate to low in the majority of the nurses $(71.5 \%)$ and survey showed that only $28.5 \%$ believed that their PA was high [Table 3]. EE and DP were observed to be significantly higher in nurses who were $\leq 35$ years $(P<0.008$; CI $95 \%$ and OR 1.27 and $P<0.03$; CI $95 \%$ and OR 0.26 , respectively).

Comparing the single and married groups, the married group was found to be more prone to $\mathrm{EE}$ $(28.17 \pm 12.1$ versus $22.3 \pm 9.6)(P=0.003$; CI $95 \%$ and OR 2.4). The staffs of high stress and high activity areas like Emergency Room (ER), Operating room (OR) and ICUs were compared with the nurses in the in-patient wards and out patient clinics. The nurses in the patients' wards and clinics were emotionally exhausted and showed an increase of DP when compared to nurses in the high stress and high activity areas $(P<0.001, \mathrm{OR}-11.1$; and $P<0.001$, CI $95 \%$ and OR -9.65 , respectively). There was no difference in the PA in both the groups

\begin{tabular}{lccc}
\hline \multicolumn{3}{l}{ Table 1: Demographic data of nurses surveyed } \\
\hline Variable & Category & Number & $\%$ \\
\hline Age (years) & $23-35$ & 106 & 53.5 \\
Marital status & $\geq 36$ & 92 & 46.5 \\
& Married & 150 & 75.75 \\
Nationality & Single & 48 & 24.25 \\
& Saudis & 37 & 18.6 \\
Location & Non-Saudis & 161 & 81.4 \\
& OPD & & 43 \\
& Wards & & 87 \\
& ICU & & 15 \\
& OR & & 21 \\
& Endoscopy & & 12 \\
\hline
\end{tabular}

Table 3: Depersonalization subscale

\begin{tabular}{|c|c|c|c|}
\hline & High & Moderate & Low \\
\hline Number of staff & $81(42 \%)$ & 59 (30.5\%) & $53(27.5 \%)$ \\
\hline Age (years) & $35.36 \pm 6.8$ & $31.29 \pm 5.2$ & $39.7 \pm 8.2$ \\
\hline $\begin{array}{l}\text { Average } \\
\text { frequency }\end{array}$ & $20.46 \pm 10.5$ & $8.75 \pm 1.9$ & $3.85 \pm 1.9$ \\
\hline $\begin{array}{l}\text { Duration on job } \\
\text { (months) }\end{array}$ & 77.7 & 38.8 & 85.8 \\
\hline
\end{tabular}

$(P<0.5)$. Non-Saudi nurses were significantly more prone to EE and PE than Saudi nurses (27.3 \pm 12.1 versus $21.6 \pm 2.9$ ) with a $P=0.004$ and 95\% CI: <9.64. There was difference between the two groups for PA ( $P=0.2,95 \%$ CI: 1.0479$)$. DP was higher in Saudi nurses when compared to non-Saudi staff $(P=0.09,95 \% \mathrm{CI}:<0.553)$ [Table 4] mong non-Saudi nurses was significantly higher when compared to Saudi nurses $(27.3 \pm 12.1$ versus $21.6 \pm 2.9$ ) with a $P=0.004$ and $95 \% \mathrm{CI}$ : $<9.64$, whereas the other parameters of DP and PA were not significant.

\section{Discussion}

The results of this study have several important implications. Firstly, our results provide evidence that there is existence of the BS among nurses working in the teaching institution in Saudi Arabia. Secondly, the study reveals that the prevalence of BS is more common than that reported from other countries, indicating that the nurses are in a serious state of different parameters of burnout. The results also illustrate that several areas of well-being of the nurses are being neglected. Nursing profession has evolved over centuries as a science and service oriented profession, despite the ongoing adversity. Very little has been done in improving their selfesteem. The effect which leaves on the nursing staff, in general, causes stress including the critical nature of their work staffing shortages requiring fewer nurses to care for more patients with less help. ${ }^{[13]}$ This leads to negative health conditions affecting personal well-being and subsequently decreases the quality and efficacy of patient care. ${ }^{[14]}$

\begin{tabular}{|c|c|c|c|}
\hline & High & Moderate & Low \\
\hline $\begin{array}{l}\text { Number } \\
\text { of staff }\end{array}$ & 88 (45.6\%) & 57 (29.5\%) & 48 (24.9\%) \\
\hline Age (years) & $35.24 \pm 6.6$ & $34.4 \pm 7.5$ & $37.46 \pm 8.9$ \\
\hline $\begin{array}{l}\text { Average } \\
\text { frequency }\end{array}$ & $37.85 \pm 6$ & $22.1 \pm 2.5$ & $10.7 \pm 3.4$ \\
\hline $\begin{array}{l}\text { Duration on } \\
\text { job (months) }\end{array}$ & 58 & 76.55 & 80.8 \\
\hline
\end{tabular}

\begin{tabular}{lccc}
\hline \multicolumn{4}{l}{ Table 4: Personal accomplishment subscale } \\
\hline & High & Moderate & Low \\
\hline Number of staff & $55(28.5 \%)$ & $60(31 \%)$ & $78(40.5 \%)$ \\
Age (years) & $35.25 \pm 9.6$ & $35.5 \pm 6.2$ & $36.1 \pm 7.2$ \\
$\begin{array}{l}\text { Average } \\
\text { frequency }\end{array}$ & $25.9 \pm 5.2$ & $34.8 \pm 3.1$ & $42.1 \pm 2.5$ \\
$\begin{array}{l}\text { Duration on job } \\
\text { (months) }\end{array}$ & 80 & 74.7 & 64.3 \\
\hline MBI scale (PA): $\leq 30=$ high, 31-36= moderate and $\geq 37=$ low
\end{tabular}


Our study is probably the first which compared the expatriate nurses and ethnic Saudi Arabian nurses, and expatriate nurses were significantly in an increased state of EE and prevalence of low PA was similar in both the groups. Reports in the literature suggest that the prevalence of BS in nurses depends upon the area where they work. Nurses working in ICU and accident and emergency (A and $\mathrm{E}$ ) room are reported to be more prone to burnout. ${ }^{[10,15]} \mathrm{It}$ was found that working in units in which life-anddeath issues are observed and taken care of every day, leading to a charged environment, becomes highly stressful and contributes to BS. ${ }^{[16-18]}$ Our results show that the nurses in high stress areas like ICU, OR and the ER coped with stress better than the nursing staff in wards. Younger age was reported as a predictor of emotional stress and burnout, ${ }^{[19,20]}$ but Koivula et al ${ }^{[21]}$ reported otherwise. Their study indicated that burnout increases with age, and staff with shorter work experience suffer with lower levels of burnout. In this study we found that EE and DP were more common in the younger nurses than in those of $\geq 36$ years of age.

Our study has its limitations. First, the nursing workforce in the sample had at least five different nationalities and the tolerance of BS and exhibiting symptoms may be different. Second, a semistructured personal interview might have produced different results from the MBI questionnaire used in our study. Some of the nurses who were surveyed may have just returned from their annual vacation, which could change the scoring of the domains as recovery might have set in.

In conclusion, our finding suggests the following:

- EE and low PA leading to burnout in quite high, when compared with the international literature;

- Age was an important predictor in the development of BS;

- the increased prevalence could be due to majority of the nurses working away from their home countries.

The clinical significance of our finding cannot be overlooked and we emphasize that hospital and nursing administrators should recognize the importance of preventing the prevalence of burnout among their staff.

\section{References}

1. Freudenberger H]. The stress burnout syndrome. J Soc Issue 1974;30:159-65.

2. Pines A, Maslach C. Characteristics of staff burnout in mental health settings. Hosp Community Psychiatry 1978;29:233-37.

3. Maslach C, Jackson SE. The measurement of burn-out. ] Occup Behav 1981;22:99-113.

4. Della Valle E, De Pascale G, Cuccaro A, Di Mare $\mathrm{M}$, Padovano L, Carbone U, et al. Burnout: Rising interest phenomenon in stressful workplace. Ann Ig 2006;18:171-7.

5. Ramirez A], Graham ], Richards MA, Cull A, Gregory WM. Mental health of hospital consultants: The effects of stress and satisfaction at work. Lancet 1996;347:724-8.

6. Lu H, While AE, Barriball KL. Job satisfaction among nurses: A literaturereview. Int ] Nurs Stud 2005;42:211-27.

7. Orzechowska A, Talarowska M, Drozda R, Mirowska D, Florkowski A, The burnout syndrome among doctors and nurses. Pol Merkur Lekarski 2008;25:507-9.

8. Cano PMA, Garcia CC, Garcia RE, Lopez AM, Parera DN. Burn-out of nurses. Enferm Intensiva 1996;7:138-46.

9. Braithwaite M. Nurse burnout and stress in the NICU. Adv Neonatal Care 2008;8:343-7.

10. Raggio B, Malacarne P. Burnout in Intensive care unit. Minerva Anestesiol 2007;73:195-200.

11. Corley MC. Moral distress of critical care nurses. Am ] Crit Care 1995;4:280-5.

12. Stechmiller JK, Yarandi HN. Predictors of burnout in critical care nurses. Heart Lung 1993;22:534-41.

13. Burke, R. Workaholism in organizations: Psychological and physical well-being consequences. Stress and Health 2000;16,11-6.

14. Gillespie M, Melby V. Burnout among nursing staff in accident and emergency and acute medicine: $\mathrm{A}$ comparative study. ] Clin Nursing 2003;12:842-51.

15. Corley MC. Moral distress of critical care nurses. Am ] Crit Care 1995;4:280-5.

16. Bartz C, Maloney JP. Burnout among intensive care nurses. Res Nurs Health 1986;9:147-53.

17. Seeley HF. The practice of anaesthesia \pm a stressor for the middle age? Anaesthesia 1996;51:571-4.

18. Neil H, Fairer JG, Coleman MP, Thurston A, Vessey MP.Mortality among male anaesthetists in the United Kingdom. Br Med ] (Clin Res Ed) 1987;295:360-2.

19. Brewer EW, Shapard L. Employee burnout: A metaanalysis of the relationship between age or years of experience. Hum Resour Dev Rev 2004;3:102-23.

20. Maslach C, Jackson SE. The measurement of experienced burnout. ] Occup Behav 1981;2:99-113.

21. Koivula M, Paunonen M, Laippala P. Burnout among nursing staff in two Finnish hospitals. ] Nurs Manage 2000;8:149-58.

Source of Support: Nil, Conflict of Interest: None declared.
Page | 229 